\title{
Explanatory Boxes
}

Forgotten Traditions in the History of Science 53

How the Practical Roots of Mathematical Knowledge Were Suppressed 94

La querelle des anciens et des modernes (Battle of the Books) 116

$\begin{array}{ll}\text { Kuhn versus Fleck } & 119\end{array}$

Special Relativity 133

$\begin{array}{ll}\text { The Metric Tensor } & 137\end{array}$

Heisenberg's Matrix Mechanics as a Transitional Synthesis 140

Marx's Value Theory and Its Counterpart in the Information Society 156

$\begin{array}{ll}\text { Representations, Power, and Transcendence } & 166\end{array}$

Three Dimensions of Knowledge in Anthropology 191

An Imaginary Global Past: The "Axial Age” 201

Sovereignty, Representation, and the Emergence of the Modern State $\quad 218$

The Intergovernmental Panel on Climate Change (IPCC) 253

An Even Shorter History of Time 337

The Emergence of Language in Recent Times $\quad 345$

$\begin{array}{ll}\text { The Onset of the Anthropocene } & 359\end{array}$

$\begin{array}{ll}\text { Geoanthropology } & 375\end{array}$

Knowledge as a Common Good $\quad 395$ 